\author{
L.S. Akhmetova \\ Al-Farabi Kazakh National University, Kazakhstan, Almaty \\ e-mail: 1.s.akhmetova@gmail.com
}

\title{
INFORMATION RESOURCES FOR THE RECONSTRUCTION OF THE COLLECTIVE PORTRAIT OF THE HEADQUARTERS OF THE 316TH RIFLE DIVISION IN 1941
}

The article talks about the author's search work for staff of the headquarters of the first body of the 316th rifle division in 1941 in the battle of Moscow. The goal: based on the open archives of Russia and Kazakhstan in 2017, to give an analysis of the personal data of staff employees of 1941 .

Methods: Methodology of comparative-historical research, methodology and technique of sociological research, comparative-historical method and analysis of statistical data, etc. Take advantage of interdisciplinary methodology, content analysis, and qualitative document analysis.

Based on the study of only recently discovered data for researchers, a number of important conclusions that refute the opinions voiced in the twentieth and early 21 st centuries were made. The headquarters included representatives of 6 nationalities of the country. More than a quarter of the headquarters were non-partisan people. $77.8 \%$ of commanders with higher and secondary education worked at the headquarters. $54.2 \%$ of staff employees did not have a military education, which is one of the reasons why the division was called militia. The division served as a bridgehead for the offensive operations of the Moscow battle, which drove the enemy hundreds of kilometers from the capital.

The practical significance of the study is the possibility of using its results in the field of culture and history.

The results of the study can be integrated into educational processes. Tips and recommendations are given to journalists and PR specialists on how to cover topics based on the search for archival materials and its analysis. Materials can be included in history, journalism and public relations textbooks of the twentieth century.

Key words: 316 rifle division, Central Archive of the Ministry of Defense of Russia, Central Archive of the Republic of Kazakhstan, journalists, archive works coverage in media.

\author{
^.С. Ахметова \\ Ә^-Фараби атындағы Қазақ, ұлттық университеті, Қазақ,стан, Алматы қ. \\ e-mail: I.s.akhmetova@gmail.com \\ 1941 жылы 316-атқыштар дивизиясы штабының ұжымдық портретін \\ қалпына келтірудің ақпараттық ресурстары
}

\begin{abstract}
Мақалада 1941 жылы Мәскеу түбіндегі шайқаста 316-атқыштар дивизиясының бірінші құрамының штабының қызметкерлері туралы автордың іздеу жұмыстары сипатталған. Мақсаты: 2017 жылы Ресей мен Қазақстанның ашық мұрағаттары негізінде 1941 жылғы штабтық қызметкерлердің сауалнамалық, деректеріне талдау жасау.

ӘАістері: салыстырмалы-тарихи зерттеудің әдіснамасы, социологиялық зерттеудің әдіснамасы мен техникасы, салыстырмалы-тарихи әдіс және статистикалық, деректерді талдау және т.б. пәнаралық әдіснаманың, контент-та^даудың және құжаттарды сапалы та^даудың артықшылықтарын пайдалану. Зерттеушілер үшін жақында ғана табылған деректерді зерттеу негізінде XX және XXI ғасырдың басында айтылған пікірлерді жоққа шығаратын бірқатар маңызды тұжырымдар жасалды. Штаб құрамында еліміздің 6 ұлт өкілі болды. Штабтың төрттен бір бөлігі партиядан тыс адамдар болды. Штабта жоғары, орта-техникалық және орта білімі бар командирлердің 77,8\% жұмыс істеАі. Штаб қызметкерлерінің 54,2\%-ында әскери білім болған жоқ, сондықтан дивизия милиция деп аталды. Аивизия мәскеулік шайқастың шабуылдау операциялары үшін плацдарм ретінде қызмет етті, жауды Астанадан жүздеген шақырымға ығыстырды.

Зерттеудің практикалық маңыздылығы оның нәтижелерін саясаттанушылардың мәдениет пен тарих саласында қолдануы болып табылады. Журналистер мен PR-мамандарға мұрағат материалдарын іздеу және оны талдау негізінде тақырыптарды қалай жариялау керектігі туралы кеңестер мен ұсыныстар берілді.

Материалдар XX ғасыр тарихы, журналистика және жұртшылықпен байланыс және басқа да әлеуметтік-гуманитарлық пәндер оқу құралдары мен оқулықтарына енгізілуі мүмкін.

Түйін сөздер: 316-атқыштар дивизиясы, Ресей Қорғаныс министрлігінің Орталық мұрағаты, Қазақстан Республикасының Орталық мұрағаты, журналистер, мұрағаттардағы жұмысты медиада жария ету.
\end{abstract}




\title{
^.С. Ахметова \\ Казахский национальный университет имени аль-Фараби, Казахстан, г. Алматы, e-mail: I.s.akhmetova@gmail.com \\ Информационные ресурсы формирования коммективного портрета штаба 316-й стрелковой Аивизии в 1941 году
}

\begin{abstract}
В статье освещается поисковая работа автора в Центральном архиве Министерства обороны России и Центра^ьном архиве Казахстана по штатным работникам штаба первого состава 316-й стрелковой дивизии в 1941 году, участвовавшего в битве под Москвой. Цель: на основе открытых архивов России и Казахстана в 2017 году дать анализ анкетных данных штабных работников Аивизии в сентябре-декабре 1941 года.

Методы: сравнительно-исторический метод и анализ статистических данных, методология сравнительно-исторического исследования, методология и техника социологического исследования, и т.А. Использование преимуществ межАисциплинарной методологии, контент-анализа и качественного анализа документов.

На основе изучения недавно открытых для исследователей данных были слеланы важные выводы, опровергающие мнения, озвученные в XX и начале XXI веков. В составе штаба были представители 6 национальностей страны. Больше четверти состава штаба были беспартийными. В штабе работали 77,8 \% командиров, имеющих высшее, среднетехническое и среднее образование. 54,2 \% штабных работников не имели военного образования, в том числе и поэтому Аивизия называлась ополченческой. В тяжелейших боях октября-декабря 1941 года дивизия послужила плацдармом Аля наступательных операций Московской битвы, отбросившей врага на сотни километров от столицы.

Практическая значимость исследования заключается в использовании его результатов в области культуры и истории политологами, журналистами, экспертами, студентами.

Аанная работа может быть представлена как практика А^я новой истории постсоветских стран и в самой республике. Ааны советы и рекомендации журналистам и PR-специалистам, как освещать темы на основе поиска и анализа архивных документов. Материалы могут быть вк^ючены в учебники по истории XX века, учебные пособия по журналистике и связям с общественностью, а также в учебные материалы других социогуманитарных Аисциплин.

Ключевые слова: 316-я стрелковая Аивизия, Центральный архив Министерства обороны России, Центральный архив Республики Казахстан, журналисты, освещение в медиа работы в архивах.
\end{abstract}

\section{Introduction}

Almost 80 years have passed since the beginning of the creation of the Panfilov's division. Repeatedly described in literature, feature films and documentaries, poems, songs and musical works, the legendary Panfilov's division continues to excite the minds and current generation of great-grandchildren of the winners.

The relevance of issues of military history, in particular the Panfilov's division, as well as the patriotic education of youth, is still important today. Since these issues have undergone such significant changes, today it is important to understand the problems of almost 80 years ago and show the current state of what they wrote and talked about in those distant years. In its history, since its creation in July 1941, the division had the deafening glory of the first winners in the Great Patriotic War. In fighting of the well-known division, there was everything: victories and defeats, defensive and offensive combats, bravery, courage and failures, retreats, encirclements and losses of staff. In war as in war. There was everything. However, at first, they wrote and spoke only in a praiseworthy form; also, there was time of denial.

Three information wars had to be survived by the Panfilov's division: in the late 40 s, in the late 80 s of the last century and in the 10th years of the XXI century (Grigoriev V. K., Akhmetova L. S., 2011; Grigoriev V. K., Akhmetova L. S., 2013; Akhmetova L. S., 2020).

The theoretical and practical significance of the topic is also necessary, since Kazakhstan has been living as a sovereign country for almost 30 years. In addition, the new challenges of the time in the era of innovative technologies made it possible to open the world to everyone and on their own. This imposes certain duties and at the same time gives the right to decide for itself and determine the importance of certain events of the past. Nevertheless, it is necessary to know history, compare facts, study it on all sides, breaking dogmas and stereotypes, study the white spots of history; to study what they did not know and did not talk about, but happened in reality, to have their own point of view. 
Information resources for the reconstruction of the collective portrait of the headquarters of the 316 th rifle division...

Unfortunately, recently there has been a tendency to mythologize history or silence certain facts. Moreover, it is observed all over the world.

The object of the study is headquarters of 316th Infantry Division named after I.V. Panfilov in 1941.

The goal: to study recently discovered materials in 2017 of the Central Archive of the Ministry of Defense of the Russian Federation (CAMD of the Russian Federation) and the Central Archive of the Republic of Kazakhstan on 316th rifle - 8th guards division named after I.V. Panfilov in 1941.

\section{Tasks:}

1. Study of the materials of the CAMD of the Russian Federation and CAR of RK.

2. Compilation of a collective portrait of headquarters of 316 th riffle division.

3. Analysis of data of employees of headquarters.

4. Show the division headquarters: why under their leadership the fighters and commanders survived, fought and won?

5. Give new knowledge for historians, political scientists, journalists, researchers and in the Internet space.

Methods: Methodology of comparative-historical research, methodology and technique of sociological research, comparative-historical method and analysis of statistical data, etc. Take advantage of interdisciplinary methodology, content analysis, and qualitative document analysis.

\section{Approaches:}

- Study of materials of the CAMD of the Russian Federation and the CAR of the Republic of Kazakhstan.

- Analysis of the biographical data of the commanders of headquarters 316 riffle division in a comparative historical study;

- Learning lessons and new challenges.

Hypotheses: the past still overcomes the present, and not only in the eyes of the elder generation, but also young people, history lessons are not learned, on the contrary they are mythologized and presented in other more positive, and sometimes negative content.

\section{Value:}

Today in Kazakhstan emphasis is placed on the study of the history of distant past centuries, and somehow the history of the twentieth century is forgotten. Complex, contradictory and little studied from modern positions, democratic approaches and other views; therefore, it is necessary to focus on the study of the history and media of Kazakhstan of different periods of the twentieth century, including the now open archives of the former USSR on military history.

\section{Background}

The article is devoted only to the first composition of the headquarters of the legendary division. They are still to face battles in October-December 1941 near Moscow, glorifying them for centuries.

The most famous division in 1941-1945 in the Soviet Union, which had to survive a lot in the war, and after the war three more information attacks passed the Panfilov's division in its almost 80-year history.

Many books and articles have been written about 316th rifle -8 Guards Division in our country [Bek A., 1943; Momysh-uli B., 1963; Nishchuk N. 1988, 2015; Selivanov F., 1959; Snegin D., 1948; Trefilov A., 1982; Usenov A., Enikeev S., Dordiy T., 1989.; Usenov A., Trefilov A., 1991; Von Bock, Fedor., 2011; Halder F., 2012; Rodric B., 2007; Borisov O., Koloskov B., 1975; Nelles T., 1969; Klaus Froh, 2010; Reinhard K., 1980; Hart B. L., 2000; Haupt V., 2010).

Working in the Central Archive of the Ministry of Defense of the Russian Federation (CAMD of the Russian Federation), I worked on two lists of headquarters of 316th infantry division of 1941.

The first list from the book of the official list of the commanding staff of 316th riffle division (RD), which was probably compiled back in AlmaAta, the second list consists of people transferred to the new book, as noted in the first list, to the division headquarters [CAMD of RF, f.8 Guards rifle division, inventory 2 , case 14 , p. 1-9; f.8 Guards rifle division, inventory 2, case 5, p. 1-8]. The second list is called «The commanding staff of the 316th rifle division on October 1, 1941». On the last page there is the inscription «Head of the 4th branch 316th RD, quartermaster of the 3rd rank Revyakin» and below the inscription "Checked» of the assistant chief - the signature of Guzenkov V.D., technician-quartermaster of the 2nd rank and date 30.09.41 [CAMD of RF, f.8 Guards rifle division, inventory 2 , case 5 , p. 7.-8].

What is the similarity and difference between the two lists?

In the first list there are 17 items: number, name of posts by state of wartime, official category, number of Military accounting specialty, number of posts by state of wartime, surname, first name, patronymic, military rank, year of birth and nationality, party status and duration, social status, military and civil education, where they come from (for the frame, indicate from which part and position, and for the district military commissariat assigned from the reserve, where it is registered); then 6 points under the common line - additional information about the 
command personnel; number of military accounting specialty, in which year he was dismissed from the Red Army, in which year he was last trained, appointed time of arrival by mobilization, place of civil service, position and phone number, home address and phone number.

The second list contains 14 items of the table: the name of posts by state, the number of posts by state, composition and category, No. of Military accounting specialty, surname, first name, patronymic and military rank, time of appointment and number of order/district/, year of birth, party membership: member of the All-Soviet Communist Party, candidate on membership of All-Soviet Communist Party, member of the Komsomol. General information. Which last educational institution he graduated from or from which class-course he dropped out. Military. Military-political and military-special, both in the Red Army and in the old army. Nationality. Participation on the fronts. Marital status (married or single), last name, first name and patronymic of the wife, father and mother, how many children. Place of birth and home address. Note on departure from the part, when and where and No. Order/District/.

According to the squad of 1941, the headquarters of the infantry division was supposed to be 76 people.

In the first list -76 items are listed, 4 vacant positions are named and at the end it is noted that 72 people are available.

The second list also has 76 posts, 4 vacancies, total: 72 people.

Thus, we will talk in the article about 72 commanders of the headquarters of the 316th infantry division.

The average age of the command staff was 34.5 years. The oldest was Major General, commander Ivan Vasilievich Panfilov, born in 1893, he was 49 years old at that time, and the youngest was the assistant to the head of the 2nd department, he was also a translator, Lieutenant Mikhail Mikhailovich Valitov, born in 1922, who was 19 years old [CAMD of RF, f.8 Guards rifle division, inventory 2 , case 14, p. 1-9].

As an important item from the second list, the question should be noted: «Did he participate on the fronts». Out of 72 people, only 16 participated in the First World War or civil wars, that is, they had combat experience, thus only $11.5 \%$ had military experience [CAMD of RF, f.8 Guards rifle division, inventory 2 , case $5, \mathrm{p} .1-8]$. It is no coincidence that even during the formation of the division, a conversation took place between Commander I.V. Panfilov and senior lieutenant
B. Momysh-uli about the fact that the division is militia, and all fighters and commanders knew about this [Central State Archive of the Republic of Kazakhstan (CSA of RK), B. Momysh-uli Foundation, f. 1432, inventory 1, case 5, p.78., Snegin D., 1983; Naumov N.F., 2006). In addition, German military leaders noted the same (Von Bock, Fedor., 2011; Halder F., 2012; Haupt V., 2010). However, in Soviet times, and even now, the military also cannot agree with this.

Extract from the order to the troops of the Central Asian Military District.

No. 0044, July 12, 1941 Tashkent

Contents: On the formation of a 316th rifle division in the District.

By August 1, 1941 in the District to form:

1. 316th rifle division by state... Dislocation in Alma-Ata city. The composition and number of units of the division in Appendix No. 4. I assign the formation of 316th infantry division to the division commander Major General PANFILOV

2. Staffing of the division with personnel, horse personnel, transport and all types of property shall be made at the expense of the resources of the District...

3. Quartering of the formed rifle division at the formation point should be carried out in public buildings (clubs, schools, winter cinema and other vacant premises).

Horse train, vehicles to place on land plots and deserts in the area of...

... On the progress of formation, the division commander to inform ME daily to the 20.00 on telegraph.

Basis: Directive of the General Staff of the Red Army of 8.7.41

Appendix: list of parts on 1 sheet

Commander of the troops of Central Asian Military District, Major General TROFIMENKO.

Brigade Commissioner Efimov.

Chief of Staff of Central Asian Military District, Major General Kazakov [CAMD of RF, f. 1063, inventory 1 , case 4 , p. 1-3].

Order on 316th rifle division.

July 14, 1941 No. 001 Alma-Ata city

1 This day I arrived in Alma-Ata city and took command of 316th rifle division

2 The division headquarters is located in the Aero Club (Proletarskaya Street)

Commander of 316th RD Major General (PANFILOV)

Deputy Chief of Staff, Captain (HOFFMAN) [CAMD of RF, f.1063, inventory 1, case 4, p. 4]. 
- Summer 1941 in Alma-Ata was hot, gruelling stuffy. But we, the fighters and officers of the 316th rifle division formed here, despite the great tension, relatively easily tolerated the heat and fatigue from difficult military service. We understood that blood is pouring at the front. We seek for battle and defend our homeland...

In fact, the formation and training of the soldiers of the division continued only a month. On July 13, regiments and units began to be equipped. On the same day that the order to be sent to the front was received, the hum of training shooting ceased. On August 18, the first echelons touched down. We were encouraged by the leaders of the party and the government of Kazakhstan.

On the eve of loading, Dzhambul arrived in the division. At the age of 95, he held courageously, believed in victory.

The Kazakhs have such a custom, - said the akyn, - to give the warmth of their hearts and blessing the to the warrior who is going into battle.
I'll execute it.

Having met with fighters, Dzhambul invited I.V. Panfilov and a group of commanders to visit him. Panfilov's soldier, a participant in this meeting, writer P. Kuznetsov conveys the farewell words of akyn.

- The fate of Kazakhs is forever connected with the Russian people. Without the Russian people, the steppe is an orphan. May this friendship be cemented by the holy blood of the batyrs in the fights with the Nazis», said Dzhambul and, putting his hand on the shoulder of the Russian general, solemnly and excitedly added:

- Lead the young Jigites, teach them, make them heroes, so that the Motherland is pleased with our sons.

I.V. Panfilov fulfilled the order of the great akyn: the warriors glorified him and their names forever (Trefilov A.. 1982).

What is the portrait of the headquarters of the 316 rifle division?

Table 1 - National composition of headquarters of 316th rifle division

\begin{tabular}{|c|c|c|}
\hline № & Nationality & Quantity \\
\hline 1 & Russians & 57 \\
\hline 2 & Ukrainians & 8 \\
\hline 3 & Kazakhs & 3 \\
\hline 4 & Jews & 2 \\
\hline 5 & Bashkir & 1 \\
\hline 6 & Georgian & 1 \\
\hline & Total & 72 \\
\hline
\end{tabular}

The command staff and fighters of the 316th rifle division were proud of the international composition of their division. At the beginning of the war, the first composition of the entire division included 36 nationalities. In table 1 , staff members of 6 nationalities are presented.

Table 2 - Party composition of headquarters of 316 th rifle division

\begin{tabular}{|c|c|c|}
\hline № & Party composition & Quantity \\
\hline 1 & $\begin{array}{c}\text { Communist party of Soviet Union or candidate to } \\
\text { Communist party of Soviet Union }\end{array}$ & 76 \\
\hline 2 & KOMSOMOL & 79 \\
\hline 3 & Non-partisan & 72 \\
\hline & Total & 79 \\
\hline
\end{tabular}


The party composition of staff workers, of course, should have been high, but professionals were taken to the division, ridiculously selecting each fighter, not only the command staff, so there are Komsomol members and non-party members in the headquarters. Note that $26.3 \%$ were non-partisan headquarters commanders.

Table 3 - Social status of staff members of 316th rifle division

\begin{tabular}{|c|c|c|}
\hline № & Social status & Quantity \\
\hline 1 & Employees & 43 \\
\hline 2 & Workers & 13 \\
\hline 3 & Peasants & 11 \\
\hline 4 & Students & 5 \\
\hline & Total & 72 \\
\hline
\end{tabular}

In Soviet times, serious attention was paid to social origin, especially commanders. This is how we observe a picture of what in general was already at the beginning of the war, employees already accounted for most of it $-59 \%$, of which, of course, there were employees personnel military, as we will see in Table 5.

Table 4 - Civilian education of headquarters of 316th rifle division

\begin{tabular}{|c|c|c|}
\hline № & Education & Quantity \\
\hline 1 & Higher and n/higher & 31 \\
\hline 2 & Average & 7 \\
\hline 3 & Average technical and average special & 3 \\
\hline 4 & 9 classes & 5 \\
\hline 5 & 7 classes & 1 \\
\hline 6 & 6 classes & 3 \\
\hline 7 & 5 classes & 2 \\
\hline 8 & 4 classes & 1 \\
\hline 9 & No education & 1 \\
\hline 10 & No record & 72 \\
\hline & Total & \multicolumn{2}{|c|}{} \\
\hline
\end{tabular}

Civilian education was high enough for employees of the headquarters of that period. $77.8 \%$ were commanders with higher and secondary education. In addition, we note that after the civil war and before the Great Patriotic War, the country was able to overcome the illiteracy of the population, and a qualified headquarters was created in the Central Asian territorial district.

Table 5 - Military formation of headquarters of 316th rifle division.

\begin{tabular}{|c|c|c|}
\hline № & Military education & Quantity \\
\hline 1 & $\begin{array}{c}\text { Military Academy and not full course of Military } \\
\text { Academy }\end{array}$ & 6 \\
\hline 2 & Military High School & 6 \\
\hline 3 & Military schools & 10 \\
\hline 4 & 8 months up to 2 years of military courses & \\
\hline
\end{tabular}


Information resources for the reconstruction of the collective portrait of the headquarters of the 316 th rifle division...

\begin{tabular}{|c|c|c|}
\hline 5 & No education & 38 \\
\hline & Total & 72 \\
\hline
\end{tabular}

If we take the percentage of employees of the division headquarters, then we note a fairly high percentage of people who did not have a military education - almost $54.2 \%$. It is no coincidence that the division was called militia. (Haupt V., 2010).

Table 6 - Places where staff workers came from (military units or assigned from the reserve of regional military commissariat, where they were registered).

\begin{tabular}{|c|c|c|}
\hline № & The place where they came from & Quantity \\
\hline 1 & Kazakhstan & 39 \\
\hline 2 & Uzbekistan & 24 \\
\hline 3 & Kyrgyzstan & 2 \\
\hline 4 & Russia & 1 \\
\hline 5 & Tajikistan & 4 \\
\hline 6 & Turkmenistan & 72 \\
\hline & Total & 2 \\
\hline
\end{tabular}

An analysis of staff workers who arrived in the division shows that the headquarters of the Central Asian Military District (CAMD), located in Tashkent, sent specialists in various military specialties from all its military units, military registration and enlistment offices, in addition, specialists from Russia arrived, probably those who were on a business trip to CAMD at that time.

Table 7 - Civilian Staff Duty Station.

\begin{tabular}{|c|c|c|}
\hline № & Civil service & Quantity \\
\hline 1 & The military who do not have civilian services & 34 \\
\hline 2 & Alma-Ata & 27 \\
\hline 3 & Tashkent & 2 \\
\hline 4 & Jambul & 1 \\
\hline 5 & Aktyubinsk & 1 \\
\hline 6 & East Kazakhstan & 1 \\
\hline 7 & Uzbekistan, Tashlak district & 2 \\
\hline 8 & Uzbekistan, Kokand & 1 \\
\hline 9 & Kyrgyzstan, Jalalabad & 1 \\
\hline 10 & Russia, Oryol Oblast & 72 \\
\hline & Total & \\
\hline
\end{tabular}

I allocate civilian service places for military personnel in Table 7 on purpose, to show once again that more than $50 \%$ did not have a military specialty. 
Table 8 - Place of birth of staff of 316th riffle division.

\begin{tabular}{|c|c|c|}
\hline № & Place of birth & Quantity \\
\hline 1 & Russia & 50 \\
\hline 2 & Kazakhstan & 12 \\
\hline 3 & Ukraine & 6 \\
\hline 4 & Belarus & 1 \\
\hline 5 & Georgia & 1 \\
\hline 6 & Latvia & 1 \\
\hline 7 & Moldova & 1 \\
\hline & Total & 72 \\
\hline
\end{tabular}

Once again, pay attention to the place of birth of staff employees. The geography of their cities is wide. We only allocated a place of birth in the Union republics.

Table 9 - Place of residence at the time of recruitment or secondment to headquarters of 316 th rifle division.

\begin{tabular}{|c|c|c|}
\hline № & Home address & Quantity \\
\hline 1 & Kazakhstan & 34 \\
\hline 2 & Uzbekistan & 16 \\
\hline 3 & Russia & 12 \\
\hline 4 & Turkmenistan & 4 \\
\hline 5 & Kyrgyzstan & 2 \\
\hline 6 & Ukraine & 1 \\
\hline 7 & Georgia & 72 \\
\hline & Total & \multicolumn{2}{|c|}{} \\
\hline
\end{tabular}

[Tables 1-9 were compiled by the author based on the materials of the data of the CAMD RF, f.8 Guards rifle division, inventory 2, case 14, p. 1-9; f.8 Guards rifle division, inventory 2 , case 5, p. 1-8].

The headquarters wrote a home address at the time their family lived at the beginning of the war. Some were single or had no relatives, so they wrote, for example, the Tashkent Infantry School.

According to the second list, 9 people were single (among them 1 - unmarried), one was divorced, but had a child, the remaining 62 people were married, mostly all had children.

71 people - men and one woman - military paramedic Karpova Praskovya Petrovna [CAMD of RF, f.8 Guards rifle division, inventory 2, case 5, p. 7.-8].

In the first list at the end on the right, where the transfer to another list is noted, there was a note that two people were killed, one was missing. We will also add the division commander to the list of those killed.

1. Panfilov Ivan Vasilievich - division commander, major general [CAMD of RF, f.8
Guards rifle division, inventory 2, case 5, p. 2.-3] killed 18.10.1941.

2. Vasiliev Alexei Andreevich - senior political instructor, senior instructor in the organization of party work - killed 22.10.1941 [CAMD of RF, f.8 Guards rifle division, inventory 2, case 5, p. 3.-4].

3. Skornyakov Vasily Pavlovich - political instructor, editorial secretary - killed near the village of Sokolovo. 27.11.1941 [CAMD of RF, f.8 Guards rifle division, inventory 2 , case 5, p. 5.-6].

4. Anashkin Mikhail Vasilievich - political instructor, senior instructor in propaganda and agitation - went missing. 19.10.1941 [CAMD of RF, f.8 Guards rifle division, inventory 2, case 5, p. 3.-4].

Thus, we cannot write that this was a complete list of those killed, missing and wounded in 1941, but it is necessary to note them. And we note that in the second list, as noted above, there is 14th last column in the table, which is called «Note on retirement from the part, when and where and no order/district/» it turned out to be empty, not filled. 
Information resources for the reconstruction of the collective portrait of the headquarters of the 316 th rifle division...

Table 10 - On the number and combat strength of the headquarters of 316th rifle division.

\begin{tabular}{|c|c|c|c|}
\hline № & Division Commandment on date & Staff & By List \\
\hline 1 & 20.09 .41$. & 76 & 71 \\
\hline 2 & 10.10 .41$. & 76 & 72 \\
\hline 3 & 20.10 .41$. & 77 & 75 \\
\hline 4 & 05.11 .41$. & 77 & 74 \\
\hline 5 & 10.11 .41$. & 77 & 76 \\
\hline 6 & 10.12 .41$. & 77 & 71 \\
\hline 7 & 16.12 .41$. & 81 & 71 \\
\hline
\end{tabular}

[Table 10 is compiled by the author based on the materials of the CAMD RF, f.8 Guards rifle division, inventory 8 , case 84 , p. $12,19,23,33$, 34, 42, 42 a.].

The number and combat composition of the 316 infantry division according to the above dates are available for all parts of the division. It is understandable that the headquarters should always be staffed according to the full program, as a higher body. In case of the departure of commanders, other commanders from lower divisions were transferred to headquarters, and such documents are available in the CAMD of the Russian Federation.

It should be noted that in the difficult battles of three months near Moscow in 1941, the division emerged victorious, but having lost more than three quarters of its composition, this is with some replenishment, which were given by Center and Stalin. And even from division management reports, we can observe that it never had $100 \%$ of its staff.

This is a description of documents postponed in the Central Archive of the Ministry of Defense of the Russian Federation according to the biographical data of the headquarters of the Panfilov Division.

We must continue to study the documents of the war years, not myphilogizing our history of the twentieth century. It is necessary to read books and memoirs, the generalized databank Memorial and other memorial pages on the Internet, to be able to distinguish facts from manipulations of both the Soviet and the current period.

What have we achieved?

A new layer of knowledge was obtained on the commanders of the headquarters of the 316 rifle division, which now allows us to arguably prove the events of those days, to understand that some documents have not survived, and it is necessary to know that manipulating and inventing what was not in the documents is unacceptable in relation to history.

\section{Results}

a) For the first time, the open archives of the Panfilov division made it possible to answer many questions that worried the public, including journalists

b) The documents of the archives at headquarters 316 of the infantry division of 1941 were analyzed, positive aspects and a number of errors made out of ignorance or consciously to manipulate the life and battles of our division were shown.

c) Positive and negative aspects in the study of the division are shown through three information wars regarding 1941. Panfilov division and the feat of 28 Panfilov's men.

In general, this is a collective portrait of the commanders of the headquarters of the 316th rifle division. Hence the conclusions:

\section{Conclusions}

1. The average age of commanders is 34.5 years.

2 . The headquarters was multinational, represented by 6 nationalities of the Soviet Union.

3. More than a quarter of the staff were not party members, which meant a union between party and non-party people to protect the fatherland.

4. More than $50 \%$ of people did not have a military education, and this figure indicates a militia division.

5. More than three quarters of the total had higher and secondary education. This is thanks to the policy of universal literacy, including in the service of the Red Army, military training.

6 . The militia division was able to repulse the elite German troops in its defense zone: in October 1941, opposing 1 to 6, and in November $1941-1: 5$, having great superiority against itself not only the numerical superiority of the enemy, but also, of course, numerical superiority in equipment, weapons, etc. 
7. Tables 8 and 9 show that it was not only the Kazakh and Kyrgyz division. At the place of birth, most of the staff were from Russia, at the place of residence - from Kazakhstan and Uzbekistan. It was true - the people's division of the entire Soviet Union.

8. The example of the headquarters of the Panfilov division shows the revival of national history by local authors.

9. Stereotypes regarding the history of the twentieth century of Kazakhstan and the USSR are gradually changing. The appearance of other national, Kazakh heroes, their inclusion in the history of Kazakhstan becomes clear. Local scientists, historians have carried out all this work.

\section{Conclusion}

The goal set at the beginning of the article has been solved. The cases of the headquarters of the Panfilov division in 1941 were studied. The statistics of the commanders of the headquarters in the fierce 1941 are shown.
The above methods of comparative historical research were used.

New challenges of time pose other goals, but without knowledge of history, changing stereotypes, using different sources and studying facts, it is impossible to move forward and qualitatively improve knowledge.

The practical significance of the study is the possibility of using its results in the field of culture and history by political scientists, journalists, experts, students, undergraduates and doctoral students of universities.

\section{Recommendations}

The results of the study can be integrated into educational processes. The experience of Kazakhstan can be presented as a practice for the new history of the post-Soviet countries and in the republic itself. Materials can be included in textbooks of the history of the twentieth century, journalism and other social and humanitarian disciplines.

\section{Литература}

Григорьев В.К., Ахметова Л.С. Яростный 1941. Размышления историков. - Алматы, 2011. - 384 с. ISBN 978-601-247167-0; Григорьев В.К., Ахметова Л.С. Панфиловцы: 60 дней подвига, ставших легендой. - Алматы, 2013. - 280 c. ISBN 978601-247-965-2; Ахметова Л.С. Панфиловцы: наша гордость, наша слава. - Алматы, 2020 - 724 с. ISBN 978-601-7419-20-2

Бек А. Волоколамское шоссе. - Алматы, 2019. ISBN 978-601-80498-4-2; Момыш-улы Б. Генерал Панфилов. - А-А., 1963. -132 с.; Нищук Н.Дорогой бессмертия. - Фрунзе. 1988; Славный путь Панфиловской дивизии. - Бишкек, 2015. ISBN 9789967-33-069-6; Селиванов Ф. Панфиловцы. - М.: Полит. литература. - 1959. - 142 с.; Снегин Д. На дальних подступах. - А-А, 1948; Трефилов А. У ворот Москвы. - А-А, 1982; Усенов А., Еникеев С., Дордий Т. Строки огненной летописи (Указатель литературы о панфиловцах 316 сд). - А-А., 1989. - 72 с.; Усенов А., Трефилов А. Мы - из Панфиловской. -А-А., - 1991. - 224 с.

Фон Бок, Федор. Я стоял у ворот Москвы. Военный дневник командующего группой армий «Центр». - М., 2011. - 512 c. ISBN 978-5-699-53085-4; Гальдер Ф. Военный дневник. 1941-1942. - М., 2012-704 с. ISBN 978-5-271-41037-6; Rodric Braithwaite; Moscow 1941; Vintage Books, New York, 2007; p. 298; Oleg Borisov, Boris Koloskov. Soviet-Chinese relations, 1945-1970; Indiana University Press (1975). ISBN 9780253354105. pp. 163-164; Toni Nelles. Zeittafel zur Militärgeschichte der Deutschen Demokratischen Republik, 1949 bis 1968; Deutscher Militärverlag (1969). OCLC 4984029. p. 204; Klaus Froh. Chronik der NVA, der Grenztruppen und der Zivilverteidigung der DDR 1956-1990. Köster (2010). ISBN 9783895747458. p. 140; Рейнгард К. Поворот под Москвой. Крах гитлеровской стратегии зимой 1941/1942 года. - М., 1980; Харт Б.Л. Битвы Третьего Рейха. Воспоминания высших чинов генералитета нацистской Германии. - М., 2000; Хаупт В. Битва за Москву. Первое решающее сражение Второй мировой. 1941-1942. -М., 2010.- 220 с. ISBN 978-5-227-02169-4

ЦАМО РФ, ф.8 гвсд, оп.2, д.14, лл. 1-9; ф.8 гвсд, оп.2, д.5, лл. 1-8.

ЦАМО РФ, ф.8 гвсд, оп. 2, д.5, лл. 7 об. -8.

ЦАМО РФ, ф.8 гвсд, оп.2, д.14, лл. 1-9. Подсчеты произведены автором.

ЦАМО РФ, ф.8 гвсд, оп.2, д.5, лл. 1-8. Подсчеты произведены автором.

Центральный Государственный Архив Республики Казахстан (ЦГА РК), фонд Б. Момыш-улы, ф. 1432, оп.1, д. 5, лл.78,112: Снегин Д. На дальних подступах. Собрание сочинений, том 5. - Алма-Ата, 1983. - 575 с. /97/

Наумов Н.Ф. В заснеженных полях Подмосковья. - Жуковский: Кучково поле. 2006. - 412. /215/

Фон Бок, Федор. Я стоял у ворот Москвы. Военный дневник командующего группой армий «Центр». - М., 2011. - 512 c. ISBN 978-5-699-53085-4; Гальдер Ф. Военный дневник. 1941-1942. - М., 2012-704 с. ISBN 978-5-271-41037-6; Хаупт В. Битва за Москву. - Первое решающее сражение Второй мировой. 1941-1942. -М., 2010.- 220 с. ISBN 978-5-227-02169-4

ЦАМО РФ, ф. 1063, оп.1, д. 4, л. 1-3.

ЦАМО РФ, ф.1063, оп.1, д. 4, л. 4.

Трефилов А. У ворот Москвы. - Алма-Ата: Казахстан. - 1982. -136 с. /7/.

Хаупт В. Битва за Москву. - Первое решающее сражение Второй мировой. 1941-1942. -М., 2010.-220 c. /160-161/. ISBN 978-5-227-02169-4 
Таблицы 1-9 составлены автором по материалам данных ЦАМО РФ, ф.8 гвсд, оп.2, д.14, лл. 1-9; ф.8 гвсд, оп.2, д.5, лл. 1-8. ЦАМО РФ, ф. 8 гвсд, оп.2, д.14, лл. 7 об. -8. ЦАМО РФ, ф. 8 гвсд, оп.2, д.14, лл. 2 об. - 3. ЦАМО РФ, ф. 8 гвсд, оп.2, д.14, лл. 3 об. -4. ЦАМО РФ, ф. 8 гвсд, оп. 2 , д. 14 , лл. 5 об. -6. ЦАМО РФ, ф. 8 гвсд, оп. 2 , д. 14 , лл. 3 об. -4.

Таблица 10 составлена автором по материалам ЦАМО РФ, ф.8 гвсд, оп.8, д.84, лл. 12, 19, 23, 33, 34, 42, 42а.

\section{References}

Grigoriev V. K., Akhmetova L. S. Yarostniy 1941. Razmishleniya Istorikov (Fierce 1941. Reflections of historians). - Almaty, 2011. - 384 p., ISBN 978-601-247-167-0; Grigoriev V. K., Akhmetova L. S. Panfilovtsy. 60 dney podviga, stavshih legendoi (Panfilov men: 60 days of feat, which became a legend). - Almaty, 2013. - 280 p., ISBN 978-601-247-965-2; Akhmetova L. S. Panfilovtsy: nashi gordost, nashi slava (Panfilov's men: our pride, our glory). - Almaty, 2020. 724 pages, ISBN 978-601-7419-20-2.

Bek A. Volokolamskoe shosse (Volokolamsk highway). - M., 1943, ISBN 978-601-80498-4-2; Momysh-uli B. General Panfilov. - A-A, 1963. -132 p.; Nishchuk N. Dorogoi bessmertiya (Road to immortality). - Frunze. 1988; Slavniy put Panfilovskoy divizii (The glorious path of the Panfilov division). - Bishkek, 2015, ISBN 978-9967-33-069-6; Selivanov F. Panfilovtsy. - M.: Polit. literature. - 1959. - 142 p.; Snegin D. Na dalnih podstupah (On the far approaches). - A-A, 1948; Trefilov A. U vorot Moskvi (At the gates of Moscow). - A-A, 1982; Usenov A., Enikeev S., Dordiy T. Stroki ognennoy letopisi (Lines of the Fire Record) (Index of Literature on Panfilov 316th RD). - A-A, 1989. - 72 p.; Usenov A., Trefilov A. Mi iz Panfilovskoy divizii (We are from Panfilov's division). $-\mathrm{A}-\mathrm{A},-1991 .-224 \mathrm{p}$.

Von Bock, Fedor. I was standing at the gates of Moscow. Military diary of the commander of the army group «Center» - M., 2011. - 512 p., ISBN 978-5-699-53085-4; Halder F. War diary. 1941-1942. - M., 2012-704 p., ISBN 978-5-271-41037-6; Rodric Braithwaite; Moscow 1941; Vintage Books, New York, 2007, p. 298; Oleg Borisov, Boris Koloskov. Soviet-Chinese relations, 1945-1970; Indiana University Press (1975). ISBN 9780253354105. pp. 163-164; Toni Nelles. Zeittafel zur Militärgeschichte der Deutschen Demokratischen Republik, 1949 bis 1968; Deutscher Militärverlag (1969). OCLC 4984029. p. 204; Klaus Froh. Chronik der NVA, der Grenztruppen und der Zivilverteidigung der DDR 1956-1990. Köster (2010). ISBN 9783895747458. p. 140; Reinhard K. Turn near Moscow. The collapse of Hitler's strategy in the winter of 1941/1942. - M., 1980; Hart B. L. Battle of the Third Reich. Memoirs of the highest ranks of the general of Nazi Germany. - M., 2000; Haupt V. Battle for Moscow. - The first decisive battle of World War II. 1941-1942. -M., 2010. - 220 p., ISBN 978-5-227-02169-4.

CAMD of RF, f.8 Guards rifle division, inventory 2, case 14, p. 1-9; f.8 Guards rifle division, inventory 2, case 5, p. 1-8.

CAMD of RF, f.8 Guards rifle division, inventory 2, case 5, p. 7.-8.

CAMD of RF, f.8 Guards rifle division, inventory 2, case 14, p. 1-9. The author made the calculations.

CAMD of RF, f.8 Guards rifle division, inventory 2, case 5, p. 1-8. The author made the calculations.

Central State Archive of the Republic of Kazakhstan (CSA of RK), B. Momysh-uli Foundation, f. 1432, inventory 1, case 5, p.7-8., Snegin D. On the far approaches. Collected works, volume 5. - Alma-Ata, 1983. - 575 p. /97/

Naumov N.F. In the snowy fields of the Moscow region. - Zhukovsky: Kuchkovo field. 2006. - 412. /215/

Von Bock, Fedor. I was standing at the gates of Moscow. Military diary of the commander of the army group «Center.» - M., 2011. - 512 p. ISBN 978-5-699-53085-4; Halder F. War diary. 1941-1942. - M., 2012-704 p., ISBN 978-5-271-41037-6; Haupt V. Battle for Moscow. - The first decisive battle of World War II. 1941-1942. -M., 2010. - 220 p., ISBN 978-5-227-02169-4

CAMD of RF, f. 1063, inventory 1, case 4, p. 1-3.

CAMD of RF, f.1063, inventory 1, case 4, p. 4.

Trefilov A. U vorot Moskvi (At the gates of Moscow). - Alma-Ata: Kazakhstan. - 1982. -136 p./7/.

Haupt V. Battle for Moscow. - The first decisive battle of World War II. 1941-1942. -M., 2010. - 220 p. /160-161/. ISBN 9785-227-02169-4

Tables 1-9 were compiled by the author based on the materials of the data of the CAMD RF, f.8 Guards rifle division, inventory

2, case 14, p. 1-9; f.8 Guards rifle division, inventory 2, case 5, p. 1-8.

CAMD of RF, f.8 Guards rifle division, inventory 2, case 5, p. 7.-8.

CAMD of RF, f.8 Guards rifle division, inventory 2, case 5, p. 2.-3.

CAMD of RF, f.8 Guards rifle division, inventory 2, case 5, p. 3.-4.

CAMD of RF, f.8 Guards rifle division, inventory 2, case 5, p. 5.-6.

CAMD of RF, f.8 Guards rifle division, inventory 2, case 5, p. 3.-4.

Table 10 is compiled by the author based on the materials of the CAMD RF, f. 8 Guards rifle division, inventory 8, case 84, p. $12,19,23,33,34,42,42$ a. 